\section{Institution of Mining and Metallurgy : Awards}

To mark the occasion of the jubilee of the Witwatersrand gold mining industry, two awards of the Gold Medal of the Institution of Mining and Metallurgy have been made, as follows: to Sir Lionel Phillips, "in recognition of his distinguished contribution to the development of the industry extending over many years ; and of his public work in many capacities" ; to Dr. James G. Lawn, "in recognition of his distinguished services to the mining profession and industry". The Consolidated Gold Fields of South Africa, Ltd., Gold Medal and premium of forty guineas have been awarded by the Institution to Dr. Munro S. Fisher, for his researches on the origin of alluvial gold.

\section{Announcements}

Ar the general meeting of the Linnean Society of London held on April 2, it was announced that His Majesty the King has been graciously pleased to continue the royal patronage of the Society. The reigning Sovereign has been the patron of the Society since it received its first charter in 1802.

Dr. Ezer GrIFfITHs, principal assistant in the Physics Department of the National Physical Laboratory, has been elected president of the British Association of Refrigeration for the session 1936-37.

AT a meeting of the Geological Society on March 25 , it was announced that the grant of the proceeds of the Daniel Pidgeon Fund for 1936 has been made to Dr. S. R. Nockolds, who proposes making a petrological study of the Garabal Hill-Glen Fyne complex, Argyll.

Prof. G. T. Morgan, director of chemical research in the Department of Scientific and Industrial Research, will deliver the Hofmann Memorial Lecture at the Imperial College of Science and Technology on May 4, at 5.30.

Mr. RICHARD K. LAw, M.P. has been appointed a member of the Medical Research Council by the Committee of Privy Council, to fill the vacancy caused by the retirement of Mr. W. S. Morrison, M.P., on becoming Financial Secretary to the Treasury.

THE Challenger Society for the Promotion of the Study of Oceanography will probably be making further grants in aid of research during the year 1936-37. The general committee is prepared to consider applications for small grants in aid of research in marine biology at a recognised laboratory during the current year. Applications, accompanied by details of the proposed research, should reach the honorary secretary, Mr. J. R. Norman, British Museum (Natural History), S.W.7, before the middle of May.

AN extended general meeting of the British Psychological Society will be held at the University of Leeds, on April 17-20. Several papers will be read and discussed, and a symposium on "Colour
Constancy" will be held with papers by Prof. David Katz, Dr. R. H. Thouless and T. M. Martin. Further information can be obtained from Dr. Ll. Wynn Jones, 7 Bideford Avenue, Leeds, 8.

The annual malaria control course for laymen, including engineers and planters, will be held on June 22-26, at the Ross Institute of Tropical Hygiene (London School of Hygiene and Tropical Medicine), Keppel Street (Gower Street), London, W.C.1, under the direction of Sir Malcolm Watson. The course is free. Further information can be obtained from the organising secretary at the Institute.

IN view of the increasing number of the tropical agricultural problems with which the Colonial Office has now to deal, the Secretary of State for the Colonies has decided to appoint an assistant agricultural adviser in addition to his present agricultural adviser, Mr. F. A. Stockdale. Dr. H. A. Tempany, now director of agriculture in the Straits Settlements and adviser on agriculture, Malay States, has been selected for this post, and it is expected that he will take up his duties during the summer.

A violent earthquake was recorded at Kew Observatory early on April 1. The first impulse arrived at $2 \mathrm{hr} .23 \mathrm{~min}$. $49 \mathrm{sec}$. G.M.T. The bearing of the epicentre, which was about 7,400 miles away, indicates that the shock occurred near the Philippine Islands, about lat. $6^{\circ} \mathrm{N}$., long. $126^{\circ} \mathrm{E}$.

Dr. Rudolf Stummen-Traumfels, professor of zoology at Graz, has been awarded the Linné Medal by the Swedish Academy of Sciences.

Applications are invited for the following appoint. ments, on or before the dates mentioned :

A scientific officer for research on internal com. bustion engines at the Royal Aircraft Establishment, South Farnborough, Hants-The Chief Superin. tendant (April 21).

Scientific officers, junior scientific officers and assistants (Grades II and III) for radio research in the Directorate of Scientific Research of the Air Ministry, The Secretary [S.2 (d)], Air Ministry, Kingsway, London, W.C.2 (April 22).

An assistant in the Department of Folk Culture and Industries, National Museum of Wales, Cardiff -The Director (April 30).

A Sorby research fellow of the Royal SocietyThe Assistant Secretary, Royal Society, Burlington House, London, S.W.1 (May 1).

A lecturer in mathematics and the method of teaching arithmetic in the Furzedown Training Col. lege (May 9), and a lecturer in physics and mathe. matics in the Avery Hill Training College (May 18) -The Education Officer, County Hall, S.E.1.

A demonstrator and assistant lecturer in chemistry in the Royal Holloway College, Englefield Green, Surrey-The Principal (May 16).

A lecturer (woman) in geography and mathematics in St. Hild's College, Durham - The Principal (June 6). 